\title{
Evaluation of comparative anti-diabetic effect of guava and mango leaves powder in streptozotocin induced diabetic rats
}

\author{
Ayesha Riaz ${ }^{1}$, Sana Arif ${ }^{1}$, Rabia Ghaffar ${ }^{1}$, Sidra Anam ${ }^{2 *}$ and Riffat \\ Shamim Aslam² \\ 1. Institute of Home Sciences, Faculty of Food, Nutrition and Home Sciences, University of Agriculture, Faisalabad- \\ Pakistan \\ 2. Institute of Microbiology, faculty of Veterinary Science, University of Agriculture, Faisalabad-Pakistan \\ *Corresponding author's email: sidraanam2924@gmail.com
}

Citation

Ayesha Riaz, Sana Arif, Rabia Ghaffar, Sidra Anam and Riffat Shamim Aslam. Evaluation of comparative antidiabetic effect of guava and mango leaves powder in streptozotocin induced diabetic rats. Pure and Applied Biology. Vol. 9, Issue 1, pp1059-1068. http://dx.doi.org/10.19045/bspab.2020.90111

\begin{tabular}{llll}
\hline \hline Received: 15/10/2019 & Revised: 22/12/2019 & Accepted: 16/01/2020 & Online First: 20/01/2020 \\
\hline
\end{tabular}

\section{Abstract}

Diabetes mellitus is one of the metabolic diseases all over the world. Guava and mango both have nutritious value and also their leaves have medicinal properties. The purpose of this study was to evaluate the comparative anti-diabetic effect of both guava and mango leaves in streptozotocin induced diabetic rats. Bothe guava and mango fruit leaves were purchased from local markets of Faisalabad, dried and grinded. Subsequently, proximate and total phenolic content analysis was performed. Four groups of rats (each with 4 rats) were made to conduct efficacy study. Group A was considered as control group fed with normal diet, group B was fed with guava leaves powder, group $\mathrm{C}$ was fed with mango leaves powder, and group D was fed with mixture of both guava and mango leaves powder. Powder was provided to rats on daily bases for 60 days. Parameters including random and fasting blood glucose level, insulin level and lipid profile including total cholesterol, high and low density lipoprotein-cholesterol were checked at the 0 day, 30 day and $60^{\text {th }}$. The obtained data was subjected to appropriate statistical analysis. The results revealed that there was significant decrease in blood glucose level (fasting + random), cholesterol, and low density lipoprotein, and increase in blood insulin level and high density lipoprotein level indicating effective anti-diabetic effect of guava and mango leaves. Overall comparison indicated the best result in group D. Guava leaves showed better anti-diabetic effect than mango leaves. In conclusion, guava leaves can be suggested for diabetic patients.

Keywords: Anti-diabetic; Blood glucose; Insulin; Metabolic

Introduction

Non-communicable diseases (NCDs) are those diseases which persist for long time and cannot be passed from one person to another. These types of diseases are affecting all age groups worldwide. NCDs include diabetes mellitus, obesity, hypercholesterolemia, hyper-lipidemia, hypertension, arteriosclerosis and cardiovascular diseases [1]. Diabetes mellitus (DM) (commonly known as diabetes) is a disease in which blood glucose level becomes abnormal [2]. It is one of the very common metabolic disease all over the world. In 2013, 382 million 
individuals were suffering from diabetes, and it is estimated that 592 million individuals will be diabetic in 2035 [3]. In Pakistan, 6.9 million number of people are suffering from diabetes and this number will increase to 11.5 million by 2025 [4]. DM is becoming common cause of mortality and morbidity in world due to metabolic and cardiovascular complications [3]. According to the International Diabetes Federation (IDF), diabetes is a $4^{\text {th }}$ important leading cause of deaths [5].

Plants are good sources of polyphenols which act as antioxidants. Free radicals have many negative effects on health and are responsible for many diseases. Risk of these diseases can be lowered by including adequate amount of polyphenols rich foods in diet [6]. Now days, approximately 1200 medicinal plants (having antidiabetic properties) have been identified [7]. Many inquiries are being done on fruits and other plant parts (stem, leaves, seeds and by-products) to study their effects on health problems as anti-hyperglycemic, anti-inflammatory, anti-cancer, cardio protective, and anti-obesity. Most commonly studied fruits are; guava, berries, mango, and passion fruits. These are rich source of vitamin $\mathrm{C}$, vitamin $\mathrm{E}$, Pigments (anthocyanins or carotenoids), dietary fiber (DF) and polyphenols [1].

Psidium guajava L (guava) is a small tree of myrtle family (Myrtaceae) [3]. It is a genus of almost 133 genera and greater than 3,800 species of tropical shrubs [8]. Mango indica L. (mango) recognized as "king of fruits" and belongs to genus Mangifera, having many species of tropical fruits belongs to the family Anacardiaceae [9]. The present study focused on comparative anti-diabetic effect of guava and mango leaves powder.

\section{Materials and methods}

The following research was conducted in National Institute of Food Science and Technology (NIFSAT) and in animal house of University of Agriculture Faisalabad
(UAF), Pakistan. Mango and Guava leaves were collected from local market of Faisalabad. Leaves were washed, sun dried and grounded by grinder. The powder obtained was stored in separate jars under room temperature until use.

\section{Proximate analysis}

Proximate analysis of both plant leaves powder was done to check the percentages of moisture content, ash, fat, crude fiber, crude protein, and nitrogen free extract. Moisture, ash, crude lipid and nitrogen contents were determined following AOAC method [10, 11]. Kjeldahl method was followed for determination of crude protein [12].

Total phenolic content (TPC) analysis

Folin-Ciocalteu method was followed for TPC analysis of guava and mango leaves powder [13].

\section{Efficacy study}

For the conduction of efficacy study, total 16 Albino rats (average weight 150-185g) were kept in animal house under proper care and were divided into four groups (each with four rats). The treatment plan for each group is given (Table 1). Diabetes was induced by Streptozotocin $(55 \mathrm{mg} / \mathrm{kg}$ body weight $)$ in all of rats. Blood samples were drawn to measure insulin level and lipid profile including total cholesterol, high density lipoprotein (HDL) and low density lipoprotein (LDL) at the $0,30^{\text {th }}$ and $60^{\text {th }}$ day of study. Blood glucose level was measured after each week throughout the period of study.

\section{Statistical analysis}

The data obtained was analyzed by factorial two-way method described by [14].

\section{Results and discussion Proximate analysis}

Proximate analysis showed that moisture contents in guava leaves was lower $(6.85 \%)$ than mango leaves $(7.3 \%)$. Ash contents in both guava and mango leaves were $7.80 \%$ and $12.70 \%$ respectively. Mango leaves also have high fat parts $(5.40 \%)$ than guava 
(2.0\%) but fiber contents were found much higher in mango leaves $(23.40 \%)$ than guava leaves $(3.6 \%)$. Same trend was observed for protein; $3.25 \%$ in guava leaves and $11.20 \%$ in mango leaves. Guava leaves showed very high percentage of nitrogen free extract (76.5 $\%)$ than mango leaves (11.2\%). In mango leaves the percentages of ash, fat, fiber and nitrogen free extract was almost same as described in the research conducted by [15]. In guava leaves, percentage of fat, fiber and protein was almost same to the research conducted by [16] except the percentage of ash and nitrogen free extract which was slightly different from percentage observed by [16]. The difference in values may be due to different environmental conditions or factors and method of crop growing.

\section{Total phenolic content analysis}

TPC analysis indicated that guava leaves have greater amount of total phenolic content (320.2 TPC/mg of Gallic acid equivalents) than mango leaves (277.4 TPC/mg of Gallic acid equivalents). These results were in correspondence to [17]. Similar results for mango leaves were also found by [18].

\section{Efficacy study}

\section{Fasting Blood glucose (FBG) and random blood glucose (RBG) level}

Results indicated that group A did not show decrease in FBG level and continuously had diabetes. Group B (fed with guava leaves) showed significant decrease in FBG level even at $60^{\text {th }}$ day $(96.25 \mathrm{mg} / \mathrm{dl})$ than group $C$ (fed with mango leaves) which showed FBG value as $117.5 \mathrm{mg} / \mathrm{dl}$ at this day (Figure 1). Statistical analysis indicated significant role of mango leaves on FBG level than all other treatments (Table 2). Group D which was fed by the mixture of guava and mango leaves showed significant decline in FBG level at $60^{\text {th }}$ day $(96.25 \mathrm{mg} / \mathrm{dl})$. Similar results about guava leaves were reported by [19]. Another study conducted by [20] described that treatment of diabetes with ethanolic extract of guava leaves gives positive results. A study conducted by [21] also reported similar results. Random blood glucose level was also determined. The results indicated that group A (fed with normal diet) did not show decrease in RBG level. At $60^{\text {th }}$ day, group D (given mixture of guava and mango leaves) showed much decline in RBG (140.5 mg/dl) than all other groups (group B with 143.5 $\mathrm{mg} / \mathrm{dl}$, group C with $148.75 \mathrm{mg} / \mathrm{dl}$ ) (Figure $2)$. Statistical analysis showed significant effect of guava leaves on lowering RBG level although mixture of both guava and mango leaves also showed lowering effect (Table 3 ). A study [22] also did related work and reported similar findings. Another study conducted by [23] also described the considerable effect of guava leaves extract on decreasing the RBG. Similar work was also reported by others $[21,24]$.

\section{Determination of Serum Insulin level $(\mu \mathrm{IU} / \mathrm{mL})$}

The findings related to serum insulin level (Figure 3) described that the treatment and days showed highly significant results and same as the interaction of both also showed highly significant results. Group C showed much increase in insulin level $(13.2 \mu \mathrm{IU} / \mathrm{mL})$ than all other groups although group B showed close value $(11.22 \mu \mathrm{IU} / \mathrm{mL})$ to this treatment group. Analysis of variance (Table 4) also described significant results. A study conducted by [22] reported that guava leaves extract has significant effect on improving the serum insulin level of diabetes induced rats. Other studies also reported similar results $[25,26]$ and supported the use of guava leaves for improving serum insulin level.

\section{Plasma Cholesterol (mg/dl)}

Results of plasma cholesterol level determination indicated that at $60^{\text {th }}$ day, its level in group B and D was significantly reduced as compared to all other groups (group A and C) (Figure 4). Statistical analysis of the plasma cholesterol level was performed. The findings related to plasma 
cholesterol level (Table 5) described that the treatments showed significant results but the interaction of both showed non-significant results. A study performed by [25] also supports the role of guava leaves in lowering plasma cholesterol level. Others [20, 27] also reported the similar results.

\section{Low Density Lipoprotein LDL (mg/dl)}

Figure 5 described the data obtained for LDL level. Statistical analysis of the plasma low density lipoprotein (LDL) level was performed. The findings related to plasma LDL level described that the treatment showed significant result, days showed highly significant results and the interaction of both also showed significant results (Table 6). A study was conducted by [25] also supported similar findings. Ethanolic extract of guava leaves significantly lowers the plasma LDL level [20].

High Density Lipoprotein (HDL) (mg/dl) Usually the level of HDL in plasma is always low but its level should be greater than 40 $\mathrm{mg} / \mathrm{dl}$ in blood. The results depicted that group A which was on normal diet did not show increase in plasma HDL level (At 0 day
$36.75 \mathrm{mg} / \mathrm{dl}$, at 30 day $39.75 \mathrm{mg} / \mathrm{dl}$ and at 60 day $35 \mathrm{mg} / \mathrm{dl}$ ) while group $\mathrm{D}$ fed with mixture of mango and guava leaves showed significant results (At 0 day $36.5 \mathrm{mg} / \mathrm{dl}$, at 30 day $46 \mathrm{mg} / \mathrm{dl}$ and at 60 day $59 \mathrm{mg} / \mathrm{dl}$ ). Group $\mathrm{B}$ as compared to group $\mathrm{C}$ showed better results in this aspect (Figure 6). Statistical analysis was also performed which also showed significant effect of group D treatment on increasing level of high density lipoprotein (Table 7). Similar findings were also reported by others $[20,25]$.

Determination of weight (g)

Weight of rats was measured at 0 day, 30 day and 60 day of the study by using weighing machine. Statistical analysis of the readings of the weight was performed which showed non-significant effect of these all treatments on weight (Table 8). At $60^{\text {th }}$ day, there was not much increase in weight of diabetic rats than non-diabetic rats (158.5g, $166.75 \mathrm{~g}, 165.25 \mathrm{~g}$, and $168.5 \mathrm{~g}$ for group A, B, $\mathrm{C}$, and $\mathrm{D}$ respectively) (Figure 7 ). A study was conducted by [25] also support similar findings.

Table 1. Treatment plan for each group of rats

\begin{tabular}{|c|c|}
\hline Groups & Treatments \\
\hline A & Normal diet (control group) \\
\hline B & Guava leaves powder $(10 \mathrm{~g} /$ day $)$ \\
\hline C & Mango leaves powder $(10 \mathrm{~g} /$ day $)$ \\
\hline D & Both Guava and Mango leaves powder $(5 \mathrm{~g}$ each $=10 \mathrm{~g} /$ day $)$ \\
\hline
\end{tabular}

Table 2. Analysis of Variance of FBG (mg/dl)

\begin{tabular}{|c|c|c|c|c|}
\hline Source & DF & SS & MS & F \\
\hline Treatment & 3 & 6547.8 & 2182.61 & $3.11^{*}$ \\
\hline days & 2 & 14267.0 & 7133.52 & $10.17^{*}$ \\
\hline Treatment $\times$ days & 6 & 5219.3 & 869.88 & $1.24^{\mathrm{NS}}$ \\
\hline Error & 36 & 25260.5 & 701.68 & \\
\hline Total & 47 & 51294.7 & & \\
*= significant $(\mathrm{P}=0.01-0.05),{ }^{\text {NS }}=$ non-significant (p>0.05)
\end{tabular}


Table 3. Analysis of Variance of RBG $(\mathrm{mg} / \mathrm{dl})$

\begin{tabular}{|c|c|c|c|c|}
\hline Source & DF & SS & MS & F \\
\hline Treatment & 3 & 48067 & 16022.4 & $3.52^{*}$ \\
\hline Days & 2 & 68306 & 34152.9 & $7.50^{* *}$ \\
\hline Treatmentxdays & 6 & 23743 & 3957.2 & $0.87^{\text {NS }}$ \\
\hline Error & 36 & 163978 & 4554.9 & \\
\hline Total & 47 & 304094 & & \\
\hline
\end{tabular}

$* *=$ highly significant $(\mathrm{p}<0.01), *=$ significant $(\mathrm{P}=0.01-0.05),{ }^{\mathrm{NS}}=$ non-significant $(\mathrm{p}>0.05)$

Table 4. Analysis of Variance of Insulin ( $\mu \mathrm{IU} / \mathrm{mL})$

\begin{tabular}{|c|c|c|c|c|}
\hline Source & DF & SS & MS & F \\
\hline Treatment & 3 & 129.816 & 43.272 & $369.80^{* *}$ \\
\hline days & 2 & 203.438 & 101.719 & $869.29^{* *}$ \\
\hline Treatment $\times$ days & 6 & 82.184 & 13.697 & $117.06^{* *}$ \\
\hline Error & 36 & 4.213 & 0.117 & \\
\hline Total & 47 & 419.650 & & \\
\hline
\end{tabular}

$* *=$ highly significant $(\mathrm{p}<0.01)$

Table 5. Analysis of Variance of Plasma Cholesterol (mg/dl)

\begin{tabular}{|c|c|c|c|c|}
\hline Source & DF & SS & MS & F \\
\hline Treatment & 3 & 1087.58 & 362.528 & $3.17^{*}$ \\
\hline days & 2 & 1838.04 & 919.021 & $8.04^{*}$ \\
\hline Treatment $\times$ days & 6 & 627.79 & 104.632 & $0.92^{\mathrm{NS}}$ \\
\hline Error & 36 & 4114.50 & 114.292 & \\
\hline Total & 47 & 7667.92 & & \\
\hline
\end{tabular}

$*=$ significant $(\mathrm{P}=0.01-0.05),{ }^{\mathrm{NS}}=$ non-significant $(\mathrm{p}>0.05)$

Table 6. Analysis of Variance of LDL (mg/dl)

\begin{tabular}{|c|c|c|c|c|}
\hline Source & DF & SS & MS & F \\
\hline Treatment & 3 & 2057.2 & 685.74 & $3.60^{*}$ \\
\hline days & 2 & 2542.9 & 1271.44 & $6.67^{* *}$ \\
\hline Treatment $\times$ days & 6 & 1101.0 & 183.49 & $0.96^{*}$ \\
\hline Error & 36 & 6866.7 & 190.74 & \\
\hline Total & 47 & 12567.8 & & \\
\hline
\end{tabular}

$* *=$ highly significant $(\mathrm{p}<0.01), *=$ significant $(\mathrm{P}=0.01-0.05)$

Table 7. Analysis of variance of HDL (mg/dl)

\begin{tabular}{|c|c|c|c|c|}
\hline Source & DF & SS & MS & F \\
\hline Treatment & 3 & 756.25 & 252.083 & $3.14^{*}$ \\
\hline days & 2 & 1110.87 & 555.437 & $6.91^{*}$ \\
\hline Treatment $\times$ days & 6 & 664.63 & 110.771 & $1.38^{*}$ \\
\hline Error & 36 & 2893.50 & 80.375 & \\
\hline Total & 47 & 5425.25 & & \\
\hline
\end{tabular}

$*=$ significant $(\mathrm{P}=0.01-0.05)$ 
Table 8. Analysis of variance of Weight (g)

\begin{tabular}{|c|c|c|c|c|}
\hline Source & DF & SS & MS & F \\
\hline Treatment & 3 & 656.17 & 218.722 & $2.27^{\mathrm{NS}}$ \\
\hline days & 2 & 23.29 & 11.646 & $0.12^{\mathrm{NS}}$ \\
\hline Treatmentxdays & 6 & 56.21 & 9.368 & $0.10^{\mathrm{NS}}$ \\
\hline Error & 36 & 3473.00 & 96.472 & \\
\hline Total & 47 & 4208.67 & & \\
\hline
\end{tabular}

NS = non-significant $(\mathrm{p}>0.05)$

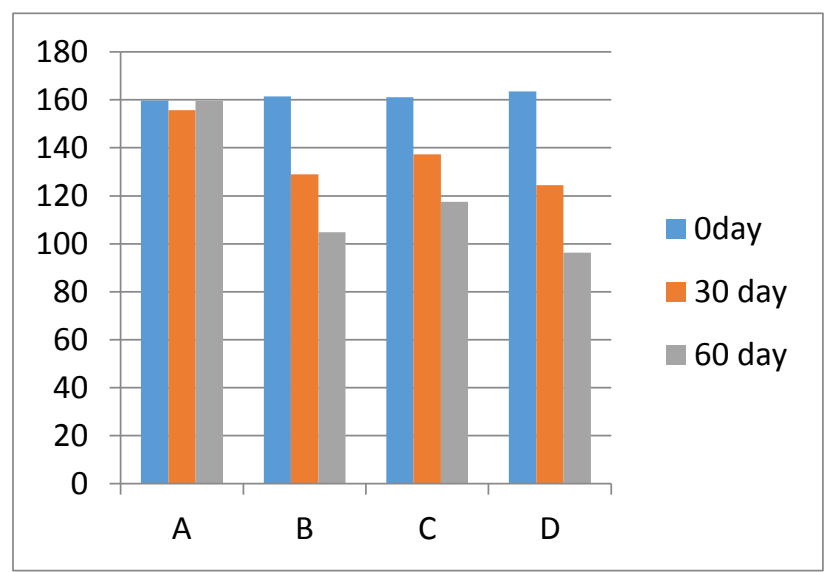

Figure 1. Effect of mango \& guava leaves powder on fasting blood glucose (mg/dl); group D rats showed maximum decrease in fasting blood glucose level while group A showed the least

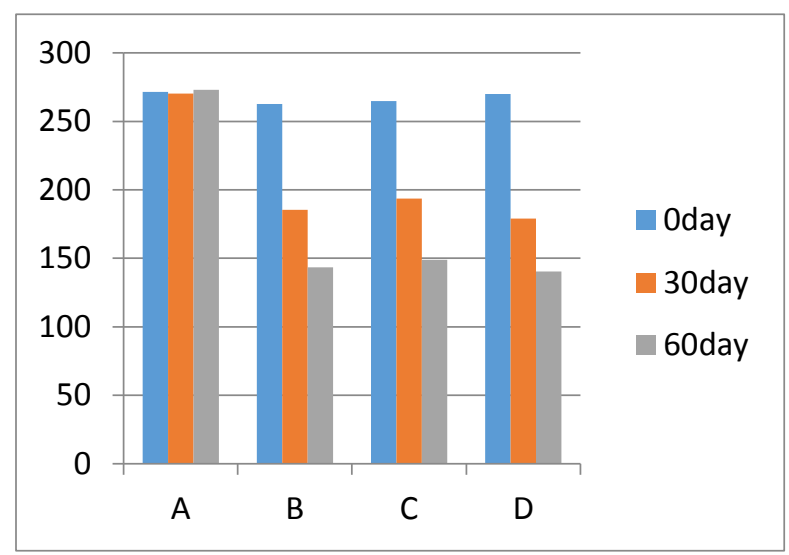

Figure 2. Effect of mango and guava leaves powder on random blood glucose (mg/dl); Graph indicated that guava leaves powder (group C) has significant antidiabetic effect than group A \& B 


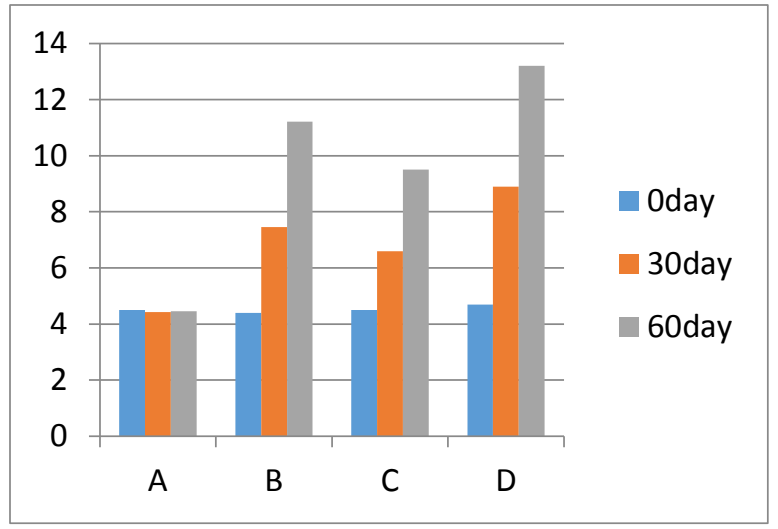

Figure 3. Effect of mango and guava leaves powder on serum insulin ( $\mu \mathrm{IU} / \mathrm{mL})$; Compared to all groups, only group $D$ indicated maximum antidiabetic effect with maximum increase in serum insulin level

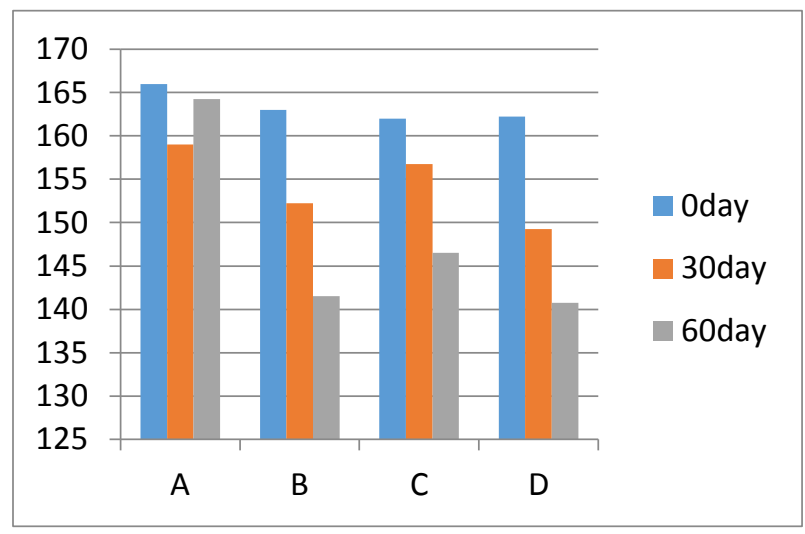

Figure 4. Effect of mango and guava leaves powder on plasma cholesterol (mg/dl) level; on $60^{\text {th }}$ day of treatment, group D, fed with mixture of mango and guava leaves powder, revealed significant effect on diabetic rats

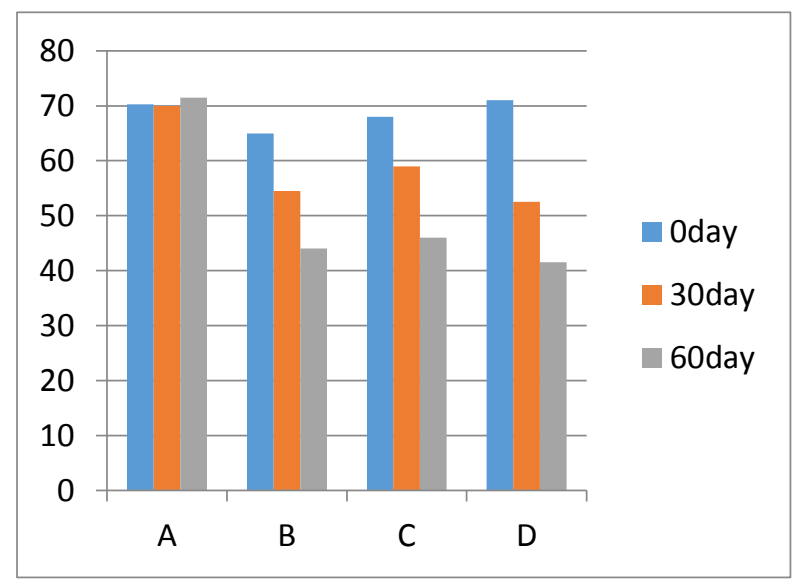

Figure 5. Effect of mango and guava leaves powder on low density lipoprotein (mg/dl) level; Group D showed best results than all other groups with maximum decline in LDL on $60^{\text {th }}$ day 


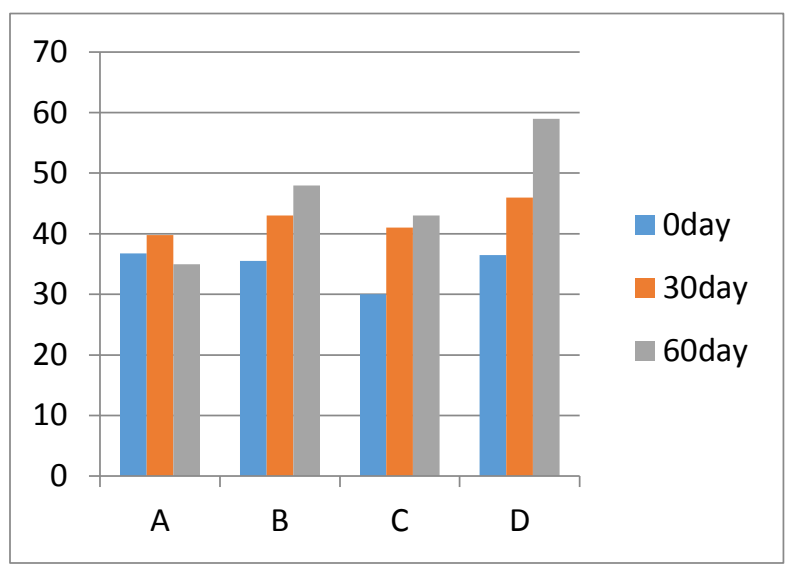

Figure 6. High density lipoprotein (mg/dl); At $60^{\text {th }}$ day of treatment, group B showed more increase in HDL than group A \& C. While group D indicated maximum increase in HDL

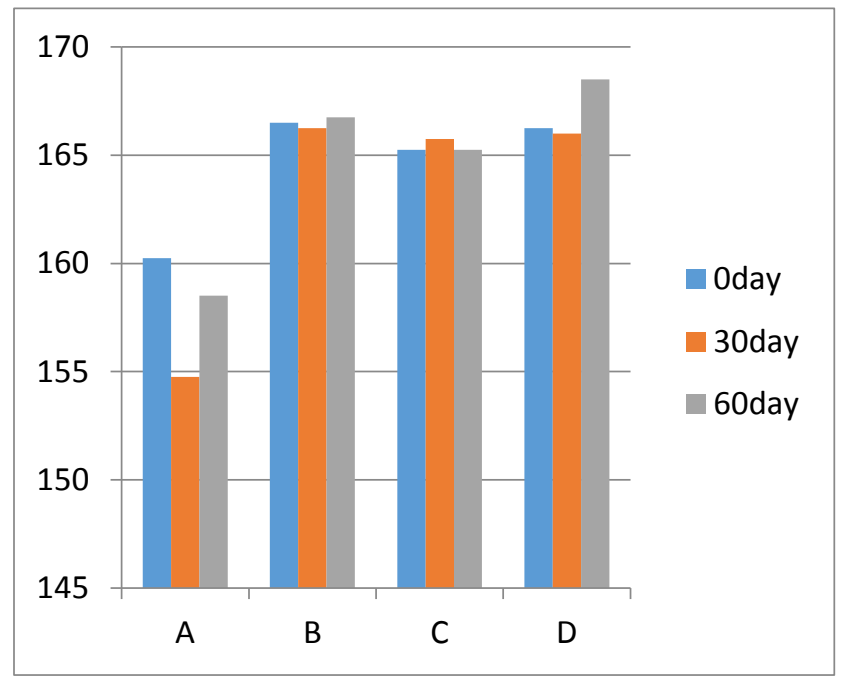

Figure 7. Weight (g) of different treatment groups; compared to all groups, weight of rats fed with mixture of guava and mango leaves powder was highest than other groups on $60^{\text {th }}$ day of treatment

\section{Conclusion}

Overall comparison of all four treatments described that group D fed with both guava and mango leaves showed the best results than all other groups. But the effect of guava leaves on diabetes is better than mango leaves.

\section{Authors' contributions}

Conceived and designed the experiments: S Arif, Performed the experiments: A Riaz, Analyzed the data: R Ghaffar \& S Anam, Contributed materials/ analysis/ tools: RS Aslam, Wrote the paper: S Anam.

\section{Acknowledgement}

The author would like to thank all the coauthors and laboratory staff for their cooperation and moral support during this study.

\section{References}

1. Perez-Beltran YE, Becerra-Verdin EM, Sayago-Ayerdi SG, Roch-Guzman NE, Garcia-lopez EG,Castaneda-Martinez A, Montalvo-Gonzalez R, RodriguezAguayo C \& Montalvo-Ganzalez E (2017). Nutritional characteristics and bioactive compounds content of guava 
purees and their effect on biochemical makers of hyperglycemic and hypercholesterolemic rats. $J$ Funct Foods 35: 447-457.

2. Awasthi A, Parween N, Singh VK, Anwar A, Prasad B \& Kumar J (2016). Daibetes: sytmptoms, cause and potential natural therapeutic methods. Adv Diabetes Metab 4: 10-23.

3. Diaz-de-Cerio E, Rodriguez-Nogales A, Algieri F, Romero M, Verardo V, Segura-Carretero A, Duarte J \& Galvez J (2017). The hypoglycemic effects of guava leaf (psidium guajava L) extract are associated with improving endothelial dysfunction in mice with diet-induced obesity. Food Res Int 96: 64-71.

4. Hayat AS \& Shaikh N (2010). Barriers and myths to initiate insulin therapy for type 2 diabetes mellitus at primary health care centers of hyderabad district. World Appl Sci J 8: 66-72.

5. Wild S, Roglic G, Green A, Sicree R \& King H (2004). Global prevalence of diabetes: estimates for the year 2000 and projections for 2030. Diabetes Care 27: 1047-1053.

6. Sugamura K \& Keaney JF (2011). Reactive oxygen species in cardiovascular disease. Free Radical Bio Med 51: 978-992.

7. Baharvand-Ahmadi B, Bahmani $M$, Tajeddini P, Naghdi N \& RafieianKopaei M (2016). An ethno-medicinal study of medicinal plants used for the treatment of diabetes. J Nephropathol 5: 44-50.

8. Shruthi SD, Roshan A, Timilsina SS \& Sunita S (2013). A review on the medicinal plant psidium guajava linn (myrtaceae). J Drug Deliv Ther 3: 162168.

9. Lauricella M, Emanuele S, Calvaruso G, Giuliano M \& Anneo AD (2017). Multifaceted healthy benefits of margifera indica linn (mango): the inestimable value of an orchard recently rooted in Sicilian rural areas. Nutrients 1: 1-14.

10. Thiex N (2008). Evaluation of analytical methods for the determination of moisture, crude protein, crude fat, and crude fiber in distillers dried grains with solubles. J AOAC Int 92(1): 61-73.

11. AOAC (2006). Association of Official Analytical Chemists. $18^{\text {th }}$ Ed. The official Methods of Analysis. AOAC Press, Arlington (USA).

12. Jones Jr JB (1991). Kjeldahl method for nitrogen determination. Kjeldahl method for nitrogen determination.

13. Folin O \& Ciocalteu V (1927). On tyrosine and tryptophane determinations in proteins. $J$ Biol Chem 73: 627-650.

14. Mason RL, Gunst RF \& Hess JL (2003). Statistical design and analysis of experiments: with applications to engineering and science. JWS 474.

15. Abel IO, David NA \& Silvanus NC (2018). Effect of feeding mango leaf and time of concentrate feeding on the performance and carcass characteristics of growing rabbits bucks. Res Rep Gen 2: 8-14.

16. Okunrobo LO, Imafidon KE \& Alabi AA (2010). Phytochemical, proximate and metal content analysis of the leaves of psidium guajava Linn (myrtaceae). Int $J$ Health Res 3: 217-221.

17. Zahidah WN, Noriham A \& Zainon MN (2013). Antioxidant and antimicrobial activities of pink guava leaves and seeds. J Trop Agric Food Sci 41: 53-62.

18. Mireya SGE, Esther RM, De LJG, Jose AR, Nelly CC, Mariol O \& Raquel CC (2018). In Vitro bioaccessibility and effect of mangifera indica (ataulfo) leaf extract on induced dyslipidemia. $J$ Med Food 21: 47-56.

19. Deguchi Y \& Miyazaki K (2010). Antihyperglycemic and anti-hyperlipidemic 
effects of guava leaf extract. Nutr Metab 7: 9-19.

20. Bahrani AHM, Zaheri H, Soltani N, Kharazmi F, Keshavarz M \& Kamalinajad M (2012). Effect of the administration of psidium guava leaves on blood glucose, lipid profiles and sensitivity of the vascular mesenteric bed to phenylephrine in streptozotocininduced diabetic rats. $J$ Diabetes Mellit 2: 138-145.

21. Bhowmik A, Khan LA, Akhter M \& Rokeya B (2009). Studies on the antidiabetic effects of Mangifera indica stem-barks and leaves on nondiabetic, type 1 and type 2 diabetic model rats. Bangladesh J Pharmacol 4: 110114.

22. Jayachandran $M$, Vinayagam R, Ambati RR, Xu B \& Chung SSM (2018). Guava leaf extract diminishes hyperglycemia and oxidative stress, prevents $\beta$-cell death, inhibits inflammation, and regulates $\mathrm{nf}-\mathrm{kb}$ signaling pathway in stz induced diabetic rats. BioMed Res Int 114.

23. Mukhtar HM, Ansari SH, Ali M, Naved $T$ \& Bhat ZA (2004). Effect of water extract of psidium guajava leaves on alloxan-induced diabetic rats. Die Pharmazie-An Int J Pharm Sci 59: 734735.

24. Aderibigbe AO, Emudianughe TS \& Lawal BAS (2001). Evaluation of the antidiabetic action of mangifera indica in mice. Phytother Res 15: 456-458.

25. Vinayagam R, Jayachandran M, Chung SSM \& Xu B. 2018. Guava leaf inhibits hepatic gluconeogenesis and increases glycogen synthesis via ampk/acc signaling pathways in streptozotocininduced diabetic rats. Biomed Pharmacother 103: 1012-1017.

26. Gondi M \& Rao UP (2015). Ethanol extract of mango (Mangifera indica L.) peel inhibits $\alpha$-amylase and $\alpha$ glucosidase activities, and ameliorates diabetes related biochemical parameters in streptozotocin (stz)-induced diabetic rats. J Food Sci Tech 52: 7883-7893.

27. Gururaja GM, Mundkinajeddu D, Kumar AS, Dethe SM, Allan JJ \& Agarwal A (2017). Evaluation of cholesterol-lowering activity of standardized extract of mangifera indica in albino wistar rats. Pharmacogn Res 9: 21-26. 